\title{
Mammary immunoglobulin transfer rates following prepartum milking
}

\author{
C. R. Baumrucker, ${ }^{*} \dagger^{1}$ C. D. Dechow, ${ }^{*}$ A. L. Macrina, ${ }^{*}$ J. J. Gross, $\dagger$ and R. M. Bruckmaier $\dagger$ \\ *Department of Animal Science, The Pennsylvania State University, University Park 16802 \\ †Veterinary Physiology, Vetsuisse Faculty, University of Bern, Switzerland CH 3001
}

\begin{abstract}
Colostrum formation is thought to occur slowly over an extended period (4 wk) prepartum. Furthermore, colostrum formation is highly variable among cows in total volume, $\operatorname{IgG}_{1}$ concentration, and mass obtained at first postpartum milking. Recent work has suggested that a rapid transfer of $\operatorname{IgG}_{1}$ to secretions may occur if animals are milked prepartum. Our objective was to establish the concentration, mass, and mass transfer rates of $\operatorname{Ig}_{1}$ in multiparous Holstein cows $(n=11$, parity $=3.6 \pm 1.1)$ milked prepartum $(-74$ to $-1 \mathrm{~h})$ and again around $4 \mathrm{~h}$ postpartum. Blood concentrations of $\operatorname{IgG}_{1}$ were very low $(<1 \mathrm{mg} / \mathrm{mL})$ in 7 cows at prepartum milking and did not decline following prepartum milking. Cows showed variability in the capacity to recover total volume, $\operatorname{IgG}_{1}$ concentration, and $\operatorname{IgG}_{1}$ mass. Three groupings of cows were considered based on the time between the 2 milkings (prepartum $+4 \mathrm{~h}$ postpartum): long-time $(-74$ to $-54 \mathrm{~h}, \mathrm{n}=3)$, medium-time $(-25$ to $-17 \mathrm{~h}, \mathrm{n}=4)$, and short-time $(<-13 \mathrm{~h}, \mathrm{n}=$ 4) groups. The average rates of transfer of these groups were $1.4 \pm 0.8,3.0 \pm 1.3$, and $25.1 \pm 15.8 \mathrm{~g} / \mathrm{h}$, respectively. The data indicate that a longer time between prepartum and postpartum milking is not a main factor in $\mathrm{IgG}_{1}$ secretion transfer. Furthermore, because blood concentrations did not change after prepartum milking and the mass of blood plasma $\operatorname{IgG}_{1}$ was not sufficient to account for the mass occurring in postpartum colostrum, a source of $\operatorname{IgG}_{1}$ other than blood circulation appears to be present during colostrogenesis.
\end{abstract}

Key words: colostrum, immunoglobulin, mammary, transfer rates

\section{INTRODUCTION}

Colostrum immunoglobulins provide passive immunization to the newborn. The importance of adequate passive transfer for minimizing morbidity and mortality has been demonstrated (Quigley and Drewry, 1998;

Received April 27, 2016.

Accepted July 8, 2016.

${ }^{1}$ Corresponding author: crb@psu.edu
Weaver et al., 2000). Concentrations of $\operatorname{IgG}_{1}$ and $\operatorname{IgG}_{2}$ in the serum of dairy cows are approximately equal, at $\sim 10$ to $20 \mathrm{mg} / \mathrm{mL}$ (Butler, 1974; Guidry et al., 1980), but selective mammary transfer of $\operatorname{IgG}_{1}$ accounts for up to a $\sim 10$-fold enhancement (Sordillo et al., 1987) in colostrum.

However, cow colostrum has extremely high animalto-animal variation in $\operatorname{IgG}_{1}$ concentration (11.8 to 74.2 $\mathrm{mg} / \mathrm{mL}$; Kehoe et al., 2007; Morrill et al., 2012) and mass (30 g to >2 kg; Baumrucker et al., 2010). Current explanations of this variation include endocrine effects (Casey and Plaut, 2007) and genetics (Doleschall et al., 2005; Mayer et al., 2005). Changes in serum prolactin and progesterone have little effect on colostrum $\operatorname{IgG}_{1}$ concentration near parturition (Gross et al., 2014). Lactation number, breed of cow, length of the dry period (Pritchett et al., 1991; Tomkins and Jaster, 1991; Mansfeld et al., 2012), and method of analysis (Li-Chan and Kummer, 1997; Gelsinger et al., 2015) may also contribute to colostrum variation.

Colostrogenesis takes place mainly in the weeks before parturition, and the secreted product has high concentrations of $\operatorname{IgG}_{1}$ (Butler, 1986). Selective $\operatorname{IgG}_{1}$ transfer from blood to secretions occurs $\sim 3$ wk before parturition (Brandon et al., 1971), as evidenced by ${ }^{125} \mathrm{I}-$ labeled blood $\operatorname{IgG}_{1}$ appearing in the secretions (Sasaki et al., 1976). Sasaki et al. (1977) also showed a modest plasma $\operatorname{IgG}_{1}$ decline from 14 to $\sim 5 \mathrm{mg} / \mathrm{mL}$ and indicated that $\operatorname{IgG}_{1}$ half-life $(5.5 \pm 1.7 \mathrm{~d})$ decreased (4.1 d) after parturition. However, this finding disagrees with current concepts of $\operatorname{IgG}_{1}$ decline, as well as the more recently reported half-life of $>20 \mathrm{~d}$ (Murphy et al., 2014) that is likely the result of recycling through the neonatal Fc receptor (FcRn) system (Kacskovics et al., 2006). Throughout the lifetime, FcRn internalizes and recycles $\operatorname{IgG}_{1}$ in many tissues (Baker et al., 2009; Giragossian et al., 2013).

Based on declining concentrations of blood $\mathrm{IgG}_{1}$, colostrum formation is thought to begin 3 to 4 wk before parturition (Brandon et al., 1971). However, individual cows might start colostrogenesis at different times prepartum. Relative to specific $\operatorname{IgG}_{1}$ transfer mechanisms, we have hypothesized that a slow rate of transfer from blood to mammary secretions, coupled with variable 
lengths of the colostrogenesis period among animals, contribute to this variation (Baumrucker and Bruckmaier, 2014). Recent evidence suggests that colostrum formation starts earlier than 4 wk prepartum (Chandra et al., 2013). Mammary secretion $\operatorname{IgG}_{1}$ concentrations were significantly higher than blood concentrations within 8 d (Winger et al., 1995; Stark et al., 2015) after the start of an induced lactation protocol similar to that used by (Macrina et al., 2011) with nonpregnant dairy cows. Initiation of colostrogenesis may be important, because different animals may start the process at different times, and if the process is slow, animals with an earlier start may gain much higher concentrations and mass, accounting for some of the documented animal variation (Baumrucker et al., 2014a). A difference in colostrogenesis start time may be related to circulating concentrations of steroids, differential sensitivity of their receptors in the mammary glands, or both, but recent work has shown little, if any, effect of progesterone decline on the end of colostrogenesis and the start of lactogenesis (Gross et al., 2014).

In a preliminary experiment, we separately milked the mammary gland quarters of a pregnant dairy cow $\sim 26 \mathrm{~h}$ before parturition and again $4 \mathrm{~h}$ after parturition. We found that $\operatorname{IgG}_{1}$ mass from the quarters was $\sim 100 \%$ recovered at $4 \mathrm{~h}$ postpartum (total of $\sim 30 \mathrm{~h}$; Baumrucker and Bruckmaier, 2014), suggesting that transfer of $\operatorname{IgG}_{1}$ can be very fast. In a recent study of pregnant cows with a standard dry period, we extended the data to show that $\operatorname{IgG}_{1}$ transcytosis can be a rapid process in the mammary glands of some animals after prepartum milking, with some interesting changes in composition (Gross et al., 2014). Milking prepartum $\left(-74\right.$ to $-1 \mathrm{~h}$ ) produced an average $\operatorname{IgG}_{1}$ concentration that was equivalent to that of control animals milked postpartum. In prepartum-milked cows, the overall mass of $\operatorname{IgG}_{1}$ was independent of the time between the 2 milkings, and $\operatorname{IgG}_{1}$ mass was not different between the 2 milkings. Total colostrum mass was similar for prepartum-milked (sum of 2 milkings) and control animals (1 milking) (Gross et al., 2014). These findings showed that the transcytosis mechanism of $\operatorname{IgG}_{1}$ can be very fast but extremely variable between animals. The objectives of the current study were (1) to critically examine the animal-to-animal variation in $\mathrm{IgG}_{1}$ transfer from blood to mammary gland secretions obtained from dairy cows milked once before parturition and again after parturition; and (2) to define the blood plasma concentration decline and mammary appearance and establish $\mathrm{IgG}_{1}$ transfer rates into the first milked postpartum colostrum. We hypothesized that prepartum milking would induce an increased flux of $\mathrm{IgG}_{1}$ from blood to mammary secretions that would appear as a blood concentration decline and recovery.

\section{MATERIALS AND METHODS}

\section{Animals and Experimental Procedures}

The experiment was conducted in accordance with the guidelines of Swiss law on animal production and approved by the Veterinary Office of the Canton Fribourg, Switzerland (permit no. 2011-40-FR). The study included 11 multiparous Holstein dairy cows (parity $3.6 \pm 1.1$ ) that were milked before parturition in the same season of 2012 and were part of a larger group of animals that has been reported (Gross et al., 2014). One cow from the previously reported group (Gross et al., 2014) was excluded due to missing samples. In the present study, our goal was to milk cows at approximately $24 \mathrm{~h}$ before estimated parturition to maximize secretion volume for the calf, and then again $4 \mathrm{~h}$ after calving. The actual prepartum milking (C1) occurred from -74 to $-1 \mathrm{~h}$ before calving; the second milking (C2) occurred at $4.6 \pm 0.3 \mathrm{~h}$ postpartum. Prepartum and postpartum milking colostrum mass was recorded, and proportional samples were frozen at $-20^{\circ} \mathrm{C}$ until analysis. Starting at $4 \mathrm{~d}$ before expected parturition, blood samples were taken from the jugular vein 3 times daily at 0600,1400 , and $2200 \mathrm{~h}$ until calving, and 1 additional sample was collected shortly before postpartum milking. Blood samples were collected in 9-mL evacuated tubes coated with EDTA and kept on wet ice until centrifugation at $2,500 \times g$ for $15 \mathrm{~min}$ at $4^{\circ} \mathrm{C}$ to harvest plasma. Plasma was subsequently stored at $-20^{\circ} \mathrm{C}$ until analysis. Animal blood volume was calculated assuming $55 \mathrm{~mL} / \mathrm{kg}$ of BW (Reynolds, 1953), and plasma volume was assumed to be $55 \%$ of blood volume.

\section{Milk and Plasma Sample Analysis}

Colostrum $\operatorname{IgG}_{1}$ concentration was determined using a modified ELISA (Bovine IgG $_{1}$ ELISA Quantitation Set; Cat. No. E10-118; Bethyl Laboratories Inc., Montgomery, TX), as described previously (Baumrucker et al., 2014a). Blood $\operatorname{IgG}_{1}$ and $\operatorname{IgG}_{2}$ were determined using kits E10-118 and E10-117, respectively. Results were expressed as IgG concentration in milligrams per milliliter or total grams (mass).

\section{Statistical Analysis}

Data were analyzed using the CORR and MIXED procedures in SAS (version 9.2; SAS, Institute, Inc., Cary, NC). The CORR procedure determined the linear relationship between the $\mathrm{C} 1$ and $\mathrm{C} 2$ variables; the MIXED procedure evaluated $\operatorname{IgG}_{1}=\operatorname{IgG}_{2}$ cow time and cow $\times$ time interaction or $\operatorname{IgG}_{2}=\operatorname{IgG}_{1}$ cow time and cow $\times$ time interaction. 


\section{RESULTS}

Prepartum milking (C1) occurred from -0.9 to -73.7 $\mathrm{h}(24.7 \pm 7.1 \mathrm{~h})$ before parturition. The second milking (C2) was conducted at $4.6 \pm 0.3 \mathrm{~h}$ postpartum. Five cows showed a decline in plasma $\operatorname{IgG}_{1}$ concentration occurring during the $4 \mathrm{~d}$ before parturition, and the other 6 showed very low concentrations with no change $(0.40 \pm 0.08 \mathrm{mg} / \mathrm{mL}$; Figure 1$)$. Seven cows exhibited very low blood concentrations of $\operatorname{IgG}_{1}(0.29 \pm 0.16 \mathrm{mg} /$ $\mathrm{mL}$ ) in the last $48 \mathrm{~h}$ before parturition. Cows did not reveal a decline in plasma $\operatorname{IgG}_{1}$ because of prepartum colostrum milking.

Average plasma $\operatorname{IgG}_{1}$ was different between cows $(P$ $<0.001)$ and changed with time $(P<0.01)$; we observed a time $\times$ cow interaction $(P<0.001)$. Average plasma $\operatorname{IgG}_{2}$ concentration (Figures 2,3 , and 4 ) was different due to 3 cows $(1607,1646$, and 1763; $P<$
0.001). Analysis using the CORR procedure between the 2 milkings of all cows indicated that colostrum $\mathrm{Ig}_{1}$ concentration and mass were positively correlated $(>0.9 ; P<0.001)$. Colostrum total mass $(\mathrm{kg}=$ yield $)$ at the second milking was negatively related to mass at the first milking $(-0.61 ; P=0.049)$.

Because the prepartum milking occurred at different times, we blocked the animals into 3 separate groups based on the time between the prepartum and the postpartum colostrum milkings. The grouping became the long-time group (Figure $2 ;<-74$ to $-54 \mathrm{~h}, \mathrm{n}=3$ ); the medium-time group (Figure $3 ;<-25$ to $-17 \mathrm{~h}, \mathrm{n}=$ 4 ); and the short-time group (Figure $4 ;<13 \mathrm{~h}, \mathrm{n}=4$ ), relative to parturition.

Two of 3 long-time cows had very low blood $\operatorname{IgG}_{1}$ concentrations during the sampling period (Figure 2; $<1 \mathrm{mg} / \mathrm{mL}$ ). In addition, 2 of the 3 recovered approximately $16.5 \%$ of the colostrum mass (Figure 2 inset);

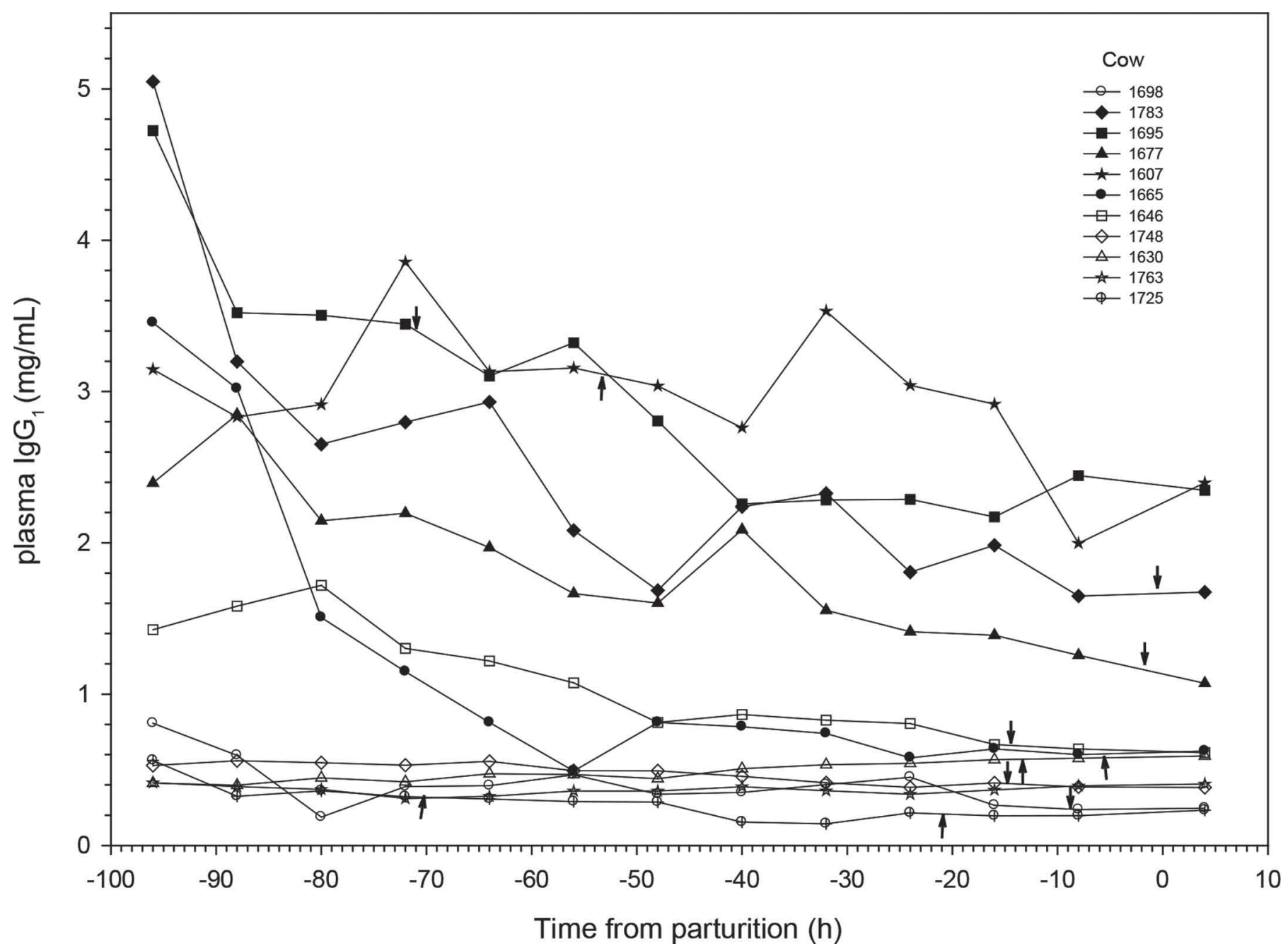

Figure 1. Prepartum milking does not affect plasma $\operatorname{IgG}_{1}$ concentration around parturition. Arrows indicate the prepartum milking time for each cow. 
the other cow recovered the equivalent initial colostrum mass $(\mathrm{C} 1)$ in the postpartum $(\mathrm{C} 2)$ milking. Two of the cows did not recover the original $\mathrm{C} 1 \mathrm{IgG}_{1}$ concentration, but the other long-time cow did (cow 1607; Figure 2 , A). None of the cows recovered the $\mathrm{C} 1 \mathrm{IgG}_{1}$ mass (Figure 2, B) despite the long time between the 2 milkings $(>54 \mathrm{~h})$. The $\operatorname{IgG}_{1}$ mass transfer rate for this group averaged $1.42 \pm 0.8 \mathrm{~g} / \mathrm{h}$.

All medium-time cows had low blood $\operatorname{IgG}_{1}$ concentrations (Figure $3 ;<1.6 \mathrm{mg} / \mathrm{mL}$ ) at the time of prepartum milking (C1). In addition, 2 of the 4 cows recovered more than the original colostrum mass (inset); the other 2 cows did not recover the initial $\mathrm{C} 1$ colostrum mass. All of the cows approached recovery of the original $\mathrm{C} 1 \mathrm{IgG}_{1}$ concentration (Figure $3, \mathrm{~A}$ ), but this was low for the range of typical colostrum concentration of 35 to $40 \mathrm{mg} / \mathrm{mL}$ (Baumrucker et al., 2010). Two cows recovered equivalent $\operatorname{Ig}_{1}$ mass (Figure $3, \mathrm{~B}$ ) in spite of the shorter time $(<25 \mathrm{~h})$ between milkings. The mass transfer rate for this group averaged $3.0 \pm 1.3 \mathrm{~g} / \mathrm{h}$.

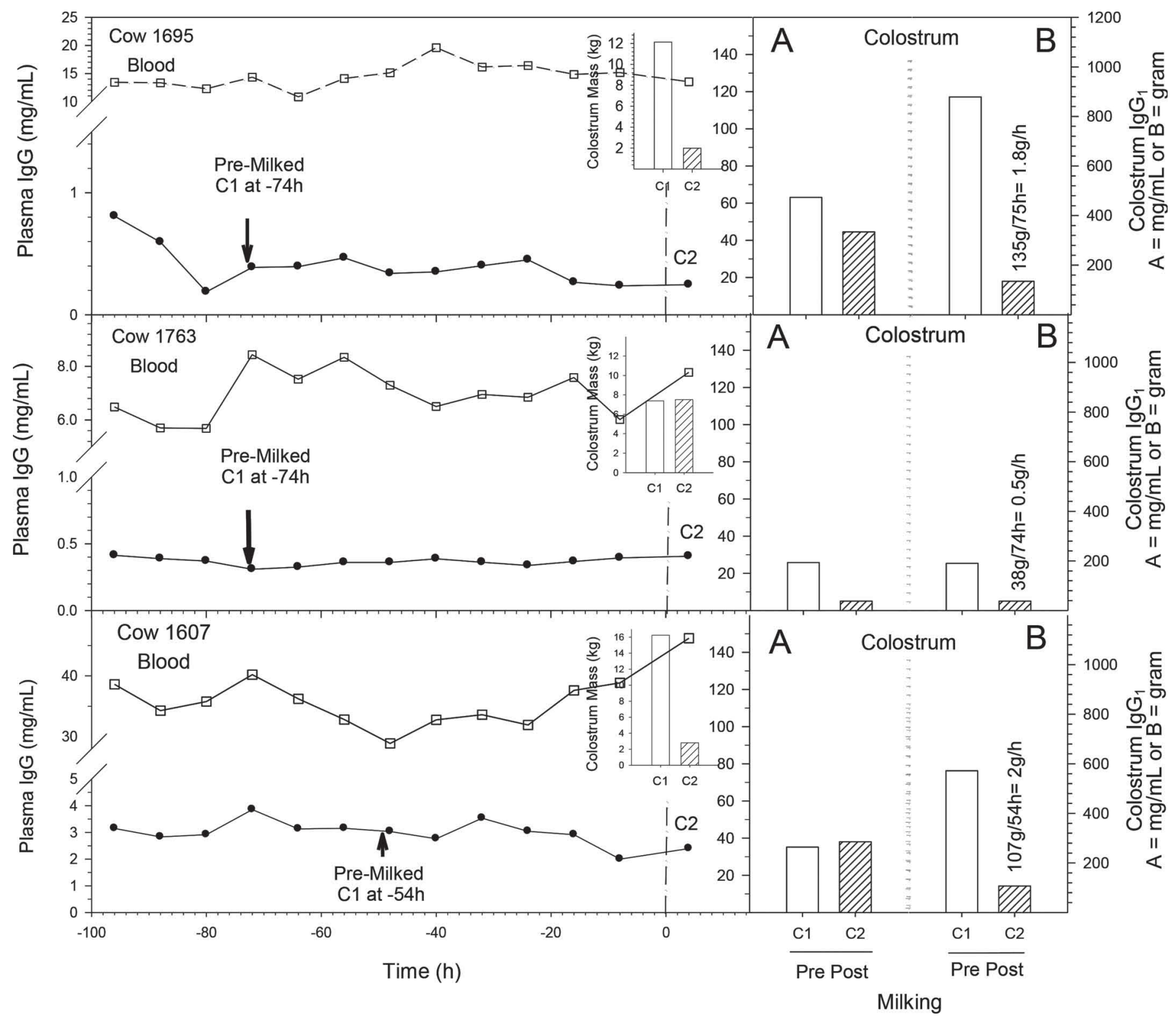

Figure 2. Prepartum (C1) and postpartum (C2) milking of colostrum in the long-time cow group (long interval between 2 milkings). The large line graph shows the plasma concentration of individual cows for $\operatorname{IgG}_{1}(\bullet)$ and $\operatorname{IgG}_{2}(\square)$. The small bar graph inset shows the colostrum total mass $(\mathrm{kg})$ at the 2 times of collection (C1 vs. C2). Graphs A and B show the concentration $(\mathrm{A}, \mathrm{mg} / \mathrm{mL})$ and total mass $(\mathrm{B}, \mathrm{g})$ of $\mathrm{IgG} \mathrm{G}_{1}$ in the collected colostrum ( $\mathrm{C} 1$ vs. $\mathrm{C} 2$ ). Graph $\mathrm{B}$ also shows the mass transfer rate of $\mathrm{IgG}_{1}$ from the $\mathrm{C} 1$ to the $\mathrm{C} 2$ collection. 


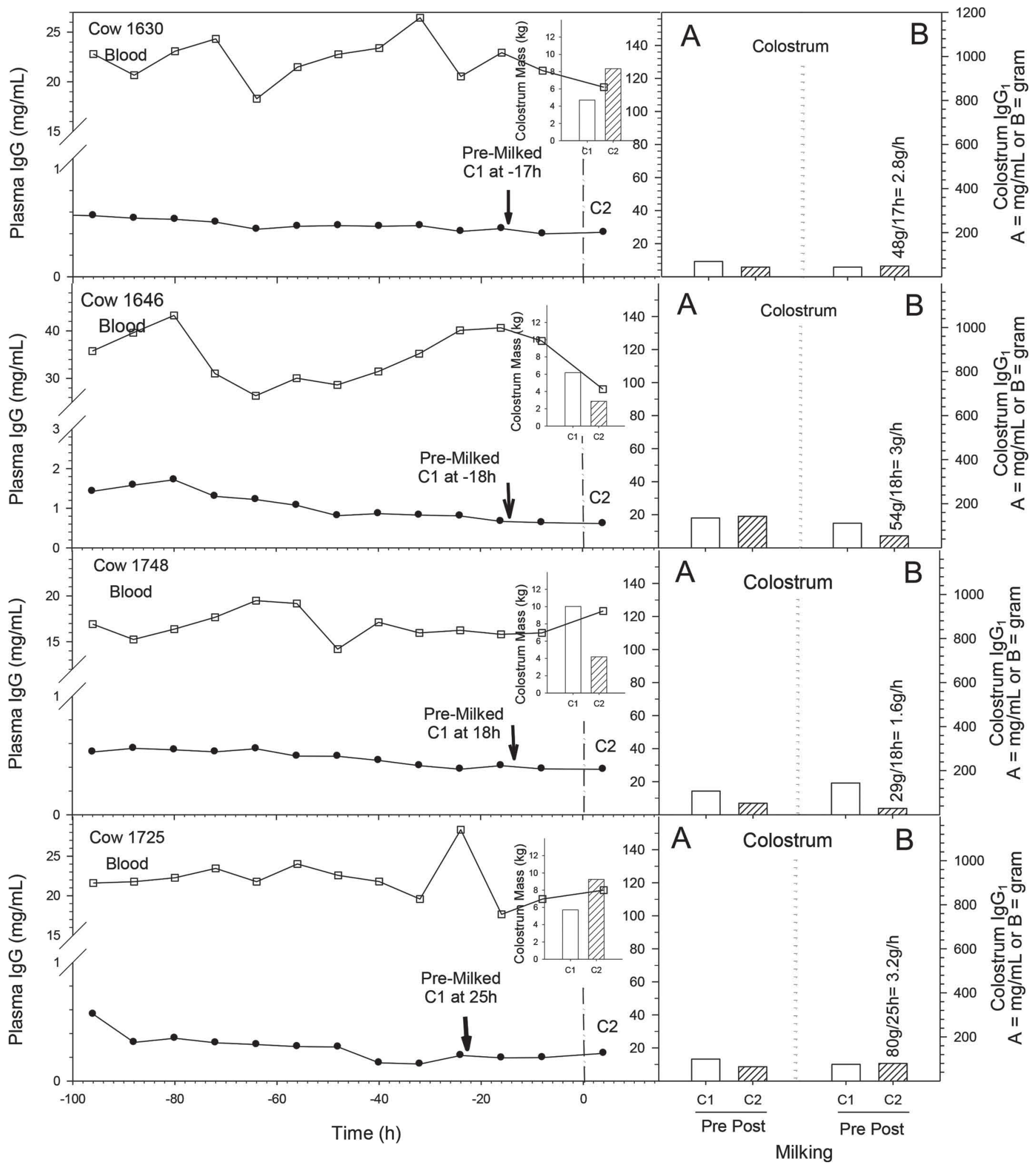

Figure 3. Prepartum (C1) and postpartum (C2) milking of colostrum in the medium-time cow group (medium interval between 2 milkings). The large line graph shows the plasma concentration of individual cows for $\operatorname{IgG}_{1}(\bullet)$ and $\operatorname{IgG}_{2}(\square)$. The small bar graph inset shows the colostrum total mass $(\mathrm{kg})$ at the 2 times of collection (C1 vs. C2). Graphs A and B show the concentration (A, mg/mL) and total mass $(\mathrm{B}$, g) of IgG in the collected colostrum (C1 vs. C2). Graph B also shows the mass transfer rate of $\mathrm{IgG}_{1}$ from the $\mathrm{C} 1$ to the $\mathrm{C} 2$ collection. 


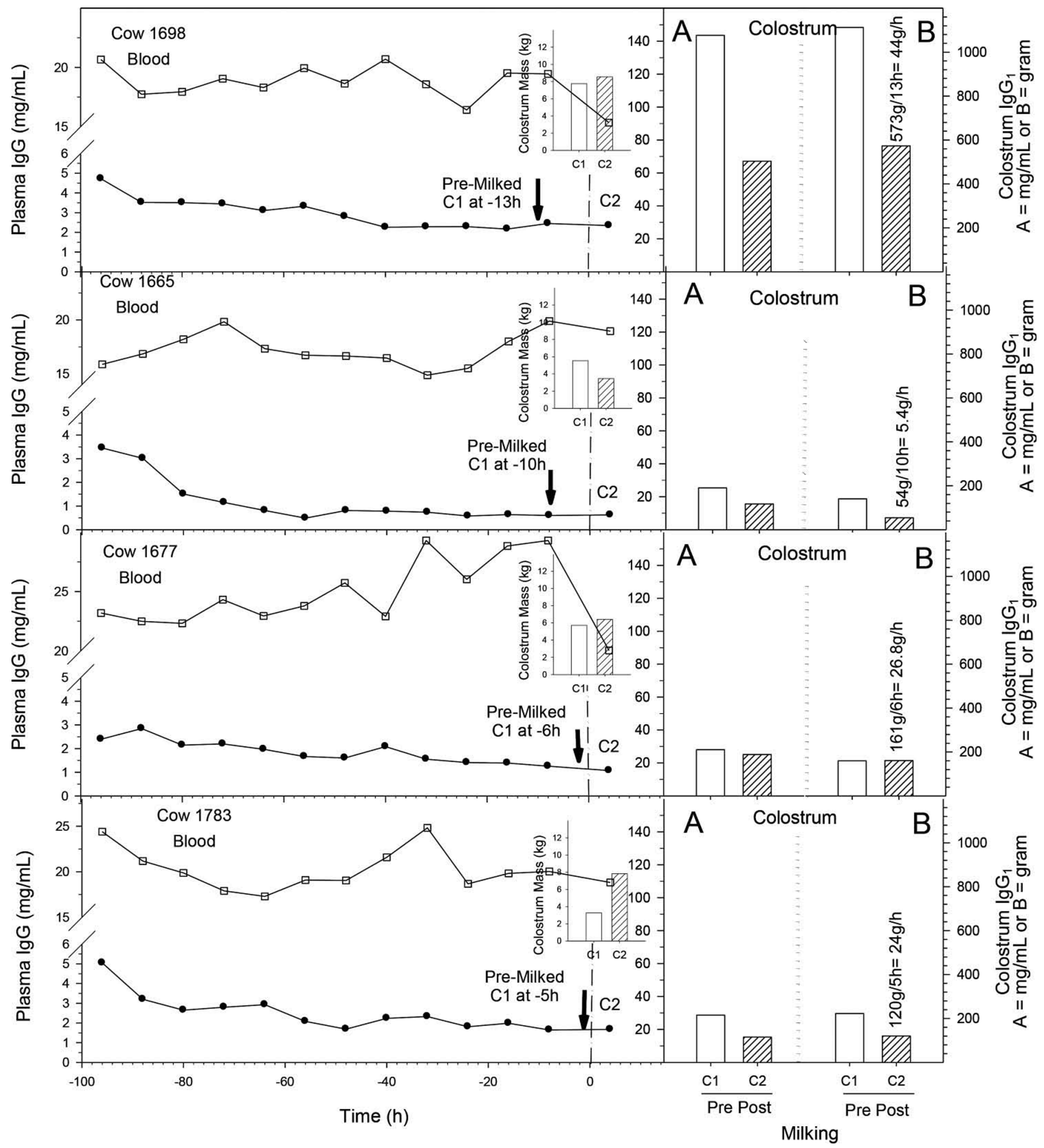

Figure 4. Prepartum (C1) and postpartum (C2) milking of colostrum in the short-time cow group (short interval between 2 milkings). The large line graph shows the plasma concentration of individual cows for $\operatorname{IgG}_{1}(\bullet)$ and $\operatorname{IgG}_{2}(\square)$. The small bar graph inset shows the colostrum total mass $(\mathrm{kg})$ at the 2 times of collection ( $\mathrm{C} 1$ vs. $\mathrm{C} 2)$. Graphs A and B show the concentration $(\mathrm{A}, \mathrm{mg} / \mathrm{mL})$ and total mass $(\mathrm{B}, \mathrm{g})$ of $\mathrm{IgG} \mathrm{G}_{1}$ in the collected colostrum ( $\mathrm{C} 1$ vs. $\mathrm{C} 2$ ). Graph B also shows the mass transfer rate of $\mathrm{IgG}_{1}$ from the $\mathrm{C} 1$ to the $\mathrm{C} 2$ collection. 
Cows in the short-time group exhibited a range of blood $\operatorname{IgG}_{1}$ concentrations $(<1$ to $<2.8 \mathrm{mg} / \mathrm{mL})$ at the time of prepartum milking $(\mathrm{C} 1)$ that was higher than that of the other groups $(P<0.05)$. In addition, 3 cows recovered equivalent or greater $\mathrm{C} 2$ colostrum mass compared with the original colostrum $\mathrm{C} 1$ mass (inset). The mass transfer rate for this group averaged $25.1 \pm$ $15.8 \mathrm{~g} / \mathrm{h}$.

We calculated the mass of $\operatorname{IgG}_{1}$ in plasma at prepartum milking $(\mathrm{C} 1)$ and compared it with $\mathrm{IgG}_{1}$ mass in colostrum at the postpartum milking ( $\mathrm{C} 2$; Table 1). The $\mathrm{C} 2$ colostrum $\mathrm{IgG}_{1}$ mass generally showed an average of $7.4 \pm 5.7$ times greater mass over the available mass in the plasma pool at the time of the C1 milking (Table 1). We know that immunoglobulins are replaced by plasma cells (Butler, 1974) and clearly would explain the results of the long-time cows and perhaps even the medium-time cows, but it is notable that cows 1698 (short time) and 1725 (medium time) showed an $\mathrm{IgG}_{1}$ mass in colostrum that was $>11$ - and 18-fold higher, respectively, than that of the plasma pool. Furthermore, we detected no change in plasma $\operatorname{IgG}_{1}$. The other 3 short-time cows exhibited 3.4-, 4.3-, and 6.0-fold higher $\mathrm{IgG}_{1}$ in $\mathrm{C} 2$ colostrum compared with plasma mass in shorter times $(<10 \mathrm{~h})$ and without any change in plasma concentration (Figure 1).

\section{DISCUSSION}

Plasma $\operatorname{IgG}_{1}$ concentrations in our study, measured in the $4 \mathrm{~d}$ before parturition, were low and had likely already declined from expected pre-colostrogenesis values of 10 to $20 \mathrm{mg} / \mathrm{mL}$ (Butler, 1974; Guidry et al., 1980). Our data generally support reports of blood declines starting earlier than our 4-d prepartum period (Brandon et al., 1971). Surprisingly, plasma concentrations of
$\mathrm{IgG}_{1}$ for most animals were extremely low $(<1 \mathrm{mg} / \mathrm{mL})$ as parturition approached $(\sim 24 \mathrm{~h}$ prepartum). This was different from literature values of 9 to $10 \mathrm{mg} / \mathrm{mL}$ occurring near to parturition using radial immune-diffusion procedures (Sasaki et al., 1976). Analysis techniques could explain some of these differences (Gelsinger et al., 2015).

Interestingly, the blood plasma concentration did not change as a result of the 1 prepartum milking of the mammary glands of pregnant dairy cows. Continuous milking without a dry period results in $\operatorname{IgG}_{1}$ accumulation in milkings during the last week before parturition, and the concentration varies among cows (Baumrucker et al., 2014b). We had hypothesized that the concentration would decline and subsequently recover as a result of the prepartum milking; this was clearly not true. However, $\operatorname{IgG}_{1}$ was transferred to new mammary secretions without any detected effect on plasma concentrations. It could be argued that the concentration was so low $(<1 \mathrm{mg} / \mathrm{mL})$ that no effect could be detected. However, the total mass transfer shown (Table 1) indicated that the plasma source, if totally used, would account for $<30 \%$ for most cows (n which was not likely to be accounted for by release from plasma cells.

The 3 figures illustrating individual cow data showed great variation in the capacity to recover colostrum mass, IgG $\mathrm{I}_{1}$ concentration, and $\operatorname{IgG}_{1}$ mass. The transfer rates of long-time cows were biased by the many hours taken to accomplish the transfer $(>54 \mathrm{~h})$. The mediumtime animals showed higher transfer rates than the longtime cows and better recovery of the colostrum mass, suggesting that the mechanisms involved in this process increase as parturition approaches. The most interesting results were those from the short-time animals. The transfer rates $(\mathrm{g} / \mathrm{h})$ were very fast and supported the concept of increasing capacity for colostrum formation

Table 1. Comparison of $\operatorname{IgG}_{1}$ concentration and calculated mass in plasma at prepartum milking and colostrum $\mathrm{IgG}_{1}$ mass at postpartum milking ${ }^{1}$

\begin{tabular}{llcccc}
\hline Cow no. & $\begin{array}{l}\text { Time milked } \\
\text { (h prepartum) }\end{array}$ & $\begin{array}{c}\text { Plasma } \\
(\mathrm{mg} / \mathrm{mL})\end{array}$ & $\begin{array}{c}\text { Plasma } \\
(\mathrm{g})\end{array}$ & $\begin{array}{c}\text { Colostrum } \\
(\mathrm{g})\end{array}$ & $\begin{array}{c}\text { Colostrum:blood } \\
\text { fold ratio }^{2}\end{array}$ \\
\hline 1783 & -1 & 1.65 & 35.0 & 120 & 3.4 \\
1677 & -2 & 1.26 & 26.1 & 161 & 6.2 \\
1665 & -6 & 0.6 & 12.3 & 54 & 4.4 \\
1698 & -9 & 2.44 & 48.9 & 573 & 11.7 \\
1630 & -13 & 0.45 & 8.9 & 48 & 5.4 \\
1748 & -14 & 0.41 & 8.7 & 29 & 3.3 \\
1646 & -14 & 0.67 & 13.2 & 55 & 4.2 \\
1725 & -21 & 0.21 & 4.3 & 80 & 18.8 \\
1607 & -50 & 3.03 & 60.0 & 106 & 6.8 \\
1763 & -70 & 0.31 & 6.2 & 38 & 16.6 \\
1695 & -71 & 0.39 & 8.2 & 135 & $7.4 \pm 5.7$ \\
Mean \pm SD & & & & &
\end{tabular}

${ }^{1}$ All cows were milked postpartum at $4.6 \pm 0.3 \mathrm{~h}$.

${ }^{2}$ Fold ratio is the colostrum $\operatorname{IgG}_{1}$ mass divided by the plasma mass. 
as parturition nears. In general, the shorter the time between the prepartum and postpartum milkings, the higher the transfer rate. These findings supported the rejection of our hypothesis that $\operatorname{IgG}_{1}$ transfer is slow and that cows with a longer colostrogenesis period would provide more $\operatorname{IgG}_{1}$ mass. Clearly, $\operatorname{IgG}_{1}$ transfer rates are variable, and more time between the 2 milkings did not result in greater $\operatorname{IgG}_{1}$ transfer.

The main question that arises from these findings is: how can the gland transfer 24 to $44 \mathrm{~g} / \mathrm{h}$ without a decline in blood $\operatorname{IgG}_{1}$ concentrations? It must be that another unaccounted pool of $\mathrm{IgG}_{1}$ is readily available for transfer to the secretions. It is interesting that the 4 animals in the short-time group generally had higher $\mathrm{IgG}_{1}$ concentration $(>25 \mathrm{mg} / \mathrm{mL})$ in the $\mathrm{C} 2$ milking than the medium-time group. The short-time animals also generally recovered the colostrum mass in the time between milkings. This would likely be influenced by a mass transfer of $\operatorname{IgG}_{1}$ that exerts high osmotic pressure (Yousef et al., 1998) and facilitates the recovery of colostrum volume. However, we do not know if the transfer rate accelerates in cows that are not milked prepartum. It is likely that prepartum milking would have an accelerating effect on $\operatorname{IgG}_{1}$ transport related to the concentration effect on biological transport mechanisms (Christensen, 1975). However, we did not observe this in the long-time group.

The timing of the decline in blood plasma $\operatorname{IgG}_{1}$ concentrations and the capacity to transfer $\operatorname{IgG}_{1}$ to secretions is highly variable between cows. We reject our working hypothesis that blood plasma concentrations would decline and recover with premilking. Furthermore, we cannot link the surprisingly low blood plasma concentrations and lack of any change in $\mathrm{IgG}_{1}$ concentration to the rates of transfer we have shown. Finally, the capacity to transfer $>44 \mathrm{~g} / \mathrm{h}$ while the plasma pool appears to be unaffected indicates that another pool of $\mathrm{IgG}_{1}$ is readily available to be moved into the secretions. We hypothesize that this source may be the mammary epithelial intracellular FcRn recycling pool or large amounts of plasma cells close to the mammary epithelial cell (Nickerson, 1989).

We know that FcRn recycling exists in many tissues (Roopenian and Akilesh, 2007; Giragossian et al., 2013) and is a component of mammary cells (Kacskovics, 2004). If mammary cell recycling is the source of $\operatorname{IgG}_{1}$ transfer, then the reported decline in blood plasma $\mathrm{IgG}_{1}$ that occurs $\sim 4$ wk before parturition (Brandon et al., 1971) may be the result of the induction of FcRn recycling in bovine mammary epithelial cells and not the direct result of $\operatorname{IgG}_{1}$ transfer to luminal secretions. A plasma cell source of $\mathrm{IgG}_{1}$ remains a viable explanation, but a decline in plasma cells occurs during involution
(Nickerson, 1989) and it is not known if this persists during colostrogenesis.

\section{CONCLUSIONS}

During a very narrow period in the last days immediately prepartum, mammary $\operatorname{IgG}_{1}$ secretion appearance rates in milking cows were highly variable. Prepartum blood concentrations of $\operatorname{IgG}_{1}$ were extremely low, and one-time prepartum milking of cows did not affect $\operatorname{IgG}_{1}$ concentrations in the circulation. Nevertheless, $\mathrm{IgG}_{1}$ appearance rates in secretions can be high and are apparently not affected by plasma $\operatorname{IgG}_{1}$ concentration. Finally, blood $\operatorname{IgG}_{1}$ mass does not account for the appearance of postpartum colostrum mass, strongly indicating an unknown pool of available $\mathrm{IgG}_{1}$.

\section{ACKNOWLEDGMENTS}

We thank Zoetis (Florham Park, NJ) for the monetary gift that made portions of this research possible.

\section{REFERENCES}

Baker, K., S. W. Qiao, T. Kuo, K. Kobayashi, M. Yoshida, W. I. Lencer, and R. S. Blumberg. 2009. Immune and non-immune functions of the (not so) neonatal Fc receptor, FcRn. Semin. Immunopathol. $31: 223-236$.

Baumrucker, C. R., and R. M. Bruckmaier. 2014. Colostrogenesis: $\mathrm{IgG}_{1}$ transcytosis mechanisms. J. Mammary Gland Biol. Neoplasia 19:103-117.

Baumrucker, C. R., A. M. Burkett, A. L. Magliaro-Macrina, and C. D. Dechow. 2010. Colostrogenesis: Mass transfer of immunoglobulin $\mathrm{G}_{1}$ into colostrum. J. Dairy Sci. 93:3031-3038.

Baumrucker, C. R., A. Stark, O. Wellnitz, C. Dechow, and R. M. Bruckmaier. 2014a. Short communication: Immunoglobulin variation in quarter-milked colostrum. J. Dairy Sci. 97:3700-3706.

Baumrucker, C. R., R. S. Zbinden, H. A. van Dorland, G. J. Remmelink, B. Kemp, A. T. van Knegsel, and R. M. Bruckmaier. 2014 b. Continuous milking of dairy cows disrupts timing of peak $\operatorname{IgG}$ concentration appearance in mammary secretions. J. Dairy Res. 81:403-409.

Brandon, M. R., D. L. Watson, and A. K. Lascelles. 1971. The mechanism of transfer of immunoglobulin into mammary secretion of cows. Aust. J. Exp. Biol. Med. Sci. 49:613-623.

Butler, J. E. 1974. Immunoglobulins of the mammary secretions. Pages 217-256 in Lactation: A Comprehensive Treatise. Vol. III. B. L. Larson, ed. Academic Press, New York, NY.

Butler, J. E. 1986. Biochemistry and biology of ruminant immunoglobulins. Prog. Vet. Microbiol. Immunol. 2:1-53.

Casey, T. M., and K. Plaut. 2007. The role of glucocorticoids in secretory activation and milk secretion, a historical perspective. J. Mammary Gland Biol. Neoplasia 12:293-304.

Chandra, G., A. Aggarwal, A. K. Singh, M. Kumar, and R. C. Upadhyay. 2013. Effect of vitamin E and zinc supplementation on energy metabolites, lipid peroxidation, and milk production in peripartum sahiwal cows. Asian-australas. J. Anim. Sci. 26:1569-1576.

Christensen, H. N. 1975. Biological Transport. 2nd ed. W. A. Benjamin Inc., Reading, MA.

Doleschall, M., Y. Zhao, B. Mayer, L. Hammarstrom, and I. Kacskovics. 2005. Isolation of the gene encoding the bovine neonatal Fc receptor. Vet. Immunol. Immunopathol. 108:145-150. 
Gelsinger, S. L., A. M. Smith, C. M. Jones, and A. J. Heinrichs. 2015 Technical note: Comparison of radial immunodiffusion and ELISA for quantification of bovine immunoglobulin $\mathrm{G}$ in colostrum and plasma. J. Dairy Sci. 98:4084-4089.

Giragossian, C., T. Clark, N. Piche-Nicholas, and C. J. Bowman. 2013. Neonatal Fc receptor and its role in the absorption, distribution, metabolism and excretion of immunoglobulin G-based biotherapeutics. Curr. Drug Metab. 14:764-790.

Gross, J. J., E. C. Kessler, V. Bjerre-Harpoth, C. Dechow, C. R. Baumrucker, and R. M. Bruckmaier. 2014. Peripartal progesterone and prolactin have little effect on the rapid transport of immunoglobulin G into colostrum of dairy cows. J. Dairy Sci. 97:2923-2931.

Guidry, J., J. E. Butler, R. E. Pearson, and B. T. Weinland. 1980. IgA, igG1, IgG2, IgM, and BSA in serum and mammary secretion throughout lactation. Vet. Immunol. Immunopathol. 1:329-341.

Kacskovics, I. 2004. Fc receptors in livestock species. Vet. Immunol. Immunopathol. 102:351-362.

Kacskovics, I., Z. Kis, B. Mayer, A. P. West Jr., N. E. Tiangco, M. Tilahun, L. Cervenak, P. J. Bjorkman, R. A. Goldsby, O. Szenci, and L. Hammarstrom. 2006. FcRn mediates elongated serum halflife of human IgG in cattle. Int. Immunol. 18:525-536.

Kehoe, S. I., B. M. Jayarao, and A. J. Heinrichs. 2007. A survey of bovine colostrum composition and colostrum management practices on Pennsylvania dairy farms. J. Dairy Sci. 90:4108-4116.

Li-Chan, E. C., and A. Kummer. 1997. Influence of standards and antibodies in immunochemical assays for quantitation of immunoglobulin G in bovine milk. J. Dairy Sci. 80:1038-1046.

Macrina, A. L., A. C. Kauf, and R. S. Kensinger. 2011. Effect of bovine somatotropin administration during induction of lactation in 15-month-old heifers on production and health. J. Dairy Sci. 94:4566-4573.

Mansfeld, R., C. Sauter-Louis, and R. Martin. 2012. [Effects of dry period length on milk production, health, fertility, and quality of colostrum in dairy cows. Invited review]. Tierarztl. Prax. Ausg. G Grosstiere Nutztiere 40:239-250.

Mayer, B., M. Doleschall, B. Bender, J. Bartyik, Z. Bosze, L. V. Frenyo, and I. Kacskovics. 2005. Expression of the neonatal Fc receptor (FcRn) in the bovine mammary gland. J. Dairy Res. 72:107-112.

Morrill, K. M., E. Conrad, A. Lago, J. Campbell, J. Quigley, and H. Tyler. 2012. Nationwide evaluation of quality and composition of colostrum on dairy farms in the United States. J. Dairy Sci. 95:3997-4005.
Murphy, J. M., J. V. Hagey, and M. Chigerwe. 2014. Comparison of serum immunoglobulin $\mathrm{G}$ half-life in dairy calves fed colostrum, colostrum replacer or administered with intravenous bovine plasma. Vet. Immunol. Immunopathol. 158:233-237.

Nickerson, S. C. 1989. Immunological aspects of mammary involution. J. Dairy Sci. 72:1665-1678.

Pritchett, L. C., C. C. Gay, T. E. Besser, and D. D. Hancock. 1991. Management and production factors influencing immunoglobulin G1 concentration in colostrum from Holstein cows. J. Dairy Sci. 74:2336-2341

Quigley, J. D., III, and J. J. Drewry. 1998. Nutrient and immunity transfer from cow to calf pre- and postcalving. J. Dairy Sci. 81:2779-2790

Reynolds, M. 1953. Plasma and blood volume in the cow using the T-1824 hematocrit method. Am. J. Physiol. 173:421-427.

Roopenian, D. C., and S. Akilesh. 2007. FcRn: The neonatal Fc receptor comes of age. Nat. Rev. Immunol. 7:715-725.

Sasaki, M., C. L. Davis, and B. L. Larson. 1976. Production and turnover of IgG1 and IgG2 immunoglobulins in the bovine around parturition. J. Dairy Sci. 59:2046-2055.

Sasaki, M., B. L. Larson, and D. R. Nelson. 1977. Kinetic analysis of the binding of immunoglobulins $\operatorname{IgG}_{1}$ and $\mathrm{IgG}_{2}$ to bovine mammary cells. Biochim. Biophys. Acta 497:160-170.

Sordillo, L. M., S. C. Nickerson, R. M. Akers, and S. P. Oliver. 1987. Secretion composition during bovine mammary involution and the relationship with mastitis. Int. J. Biochem. 19:1165-1172.

Stark, A., O. Wellnitz, C. Dechow, R. Bruckmaier, and C. Baumrucker. 2015. Colostrogenesis during an induced lactation in dairy cattle. J. Anim. Physiol. Anim. Nutr. (Berl.) 99:356-366.

Tomkins, T., and E. H. Jaster. 1991. Preruminant calf nutrition. Vet. Clin. North Am. Food Anim. Pract. 7:557-576.

Weaver, D. M., J. W. Tyler, D. C. VanMetre, D. E. Hostetler, and G. M. Barrington. 2000. Passive transfer of colostral immunoglobulins in calves. J. Vet. Intern. Med. 14:569-577.

Winger, K., C. C. Gay, and T. E. Besser. 1995. Immunoglobulin G1 transfer into induced mammary secretions: The effect of dexamethasone. J. Dairy Sci. 78:1306-1309.

Yousef, M. A., R. Datta, and V. G. J. Rodgers. 1998. Free-solvent model of osmotic pressure revisited: Application to concentrated IgG solution under physiological conditions. J. Colloid Interface Sci. 197:108-118 